\title{
EMPOWERING WOMEN SELF HELP GROUPS THROUGH MICROFINANCE DURING COVID-19: A CASE STUDY OF WOMEN SHG
}

\author{
Dr. Richa Sharma \\ Assistant Professor \\ Sharda University, India \\ E-mail: richz2009@gmail.com \\ Dr. Saurabh Mishra \\ Assistant Professor \\ Department of Management Studies \\ Indian Institute of Information Technology Allahabad, India \\ E-mail: saurabhmishra@iiita.ac.in \\ Dr. Shashikant Rai \\ Assistant Professor \\ Department of Management Studies \\ Indian Institute of Information Technology Allahabad, India \\ E-mail: shashikant@iiita.ac.in
}

\begin{abstract}
The paper describes the mitigating effect of self-help groups in India during and post covid-19 situation. The study examines the potential opportunities and challenges concerning the contextual differences across and within the countries. Self-help group has been important in empowering its members by providing opportunities for livelihood support and income generator during the covid-19 situation. The self-help group played a very important role during the covid19 situation as half of the SHG was involved in community awareness and infection prevention activities in their community. The study identifies a potential mechanism through which women's groups may be affected by covid-19 situations.
\end{abstract}

Keywords: SHG, Covid-19, Micro-Finance, Social Development, Local Community.

JEL Classification Codes: G21, I3.

\section{INTRODUCTION}

Just like other disasters this too has had hits the vulnerable more and had a differential impact on men and women. Women are more vulnerable than men in various ways which reveals the continuing gender inequality concern especially in the case of the developing world which was also proved during the outbreak of 2014 Ebola and Zika virus of 2015 (Davies \& Bennett, 2016).SHG has played a major role across the globe in reducing the challenges of livelihood, especially among women. These groups have been very important in generating income for the 
vulnerable section of the society during such pandemic situation. The government of India supporting these sections continuously by various schemes such as Day- NRLM under the Ministry of Rural Development (MoRD), which employs around 69 million women under SHG (Tankha, 2012). For the last 15 years mission is working for the livelihood of poor rural women and has been a valuable contributory source during the pandemic time. SHG has contributed holistically towards the engagement of the community for social and economic needs during the outbreak of a pandemic. SHG group which is mostly represented by females is creating awareness among in local community through phone calls, wall painting, pamphlets, and social media. The effort of these SHG has consolidated to work on the issues such as the use of masks, social distancing, and psychosocial issues of migrants, quarantine, mental health, and well-being of elderly people. These SHG has been very important in dealing with the current pandemic situation as thorough their decentralized (Rathod, \& Pooja, 2015). These SGH has been very important in dealing with the current pandemic situation as through their decentralized production around 20,000 SHG produced over 19 million masks and 100,000 liters of sanitizer all over India. Due to their production at the local level, it has been delivered to the market without involving huge costs for logistics and transportation. SHG has also initiated work through Vulnerability Reduction Fund or with the support of state governments and local administration especially in Maharashtra Such as Mahila Arthik Vikas Mahamandal (MAVIM)and similar other groups, played a crucial role in combating the socio-economic effect of pandemic (Mengstie, \& Singh, 2020; Mahajan \& Kamble, 2011).MAVIM has contributed around 11 lakhs Rupees in state government relief fund through running donation campaign at the community level. Jeevika an organization in Bihar has used Information and communication technology to spread awareness and preparedness during the tough time. Many have also used interesting measures in spreading awareness of the pandemic through the number of activities such as wall painting done by Prerna in UP to communicating the message of social distancing. To deal with deprived migrants workers some SHG such as in Jharkhand opened a $24 \times 7$ helpline called Didi to provide authentic information to migrant laborers during the evacuation and return process to their hometown. SHG played an important role in financial inclusion in rural areas. During the distressing time, these women SHG were helping with the distribution of pensions by providing door to door services to the remote communities to access their account credit from the DBT scheme. The women's are worst suffered during the tough time but through this SHG they played a very important role by providing safety to the society through the vulnerable social group during the tough time (Llewelyn, 2006)

\section{History}

Micro-financing was introduced in Asian nations within the Eighties as an answer to economic conditions and to empower ladies. Being one of the best schemes for rural credit microfinance store faced a lot of challenges in the rural areas (Rogaly, 1996). Micro-finance may be a style of banking service provided to people who have issues in accessing formal monetary services. The benefit of Microfinance is for those who fall into a low-income group and do not have any financial support in rural areas of the country (Singh, Roy \& Pandiya, 2020). In developing countries like Asian nations, monetary services through formal channels don't meet the strain of the agricultural poor, thus micro-finance will facilitates small-scale businesses by providing them larger monetary stability. One of the major initiatives was taken by Kudumbashree, in Kerala in 1998. This female-led community organization of Neighborhood teams (NHGs) brings girls from 
rural and concrete areas along to fight for his or her rights and helps empower them (Venugopalan, 2014).

Earlier micro fiancé anticipated providing credit to poor in semi-urban areas at the subsidized rate of interest through organized financial institutions. The current microfinance system targets rural and urban poor households with more emphasis on women borrowers. The finance for these assets is based on the principles of borrower knows the best. Microfinance creates access to skilled labor through training and education social capital built through representatives by promoting a democratic system enabling poverty reduction. It serves as a tool for liquidity for the poorest in society this helps them in strengthening their consumption pattern and reduces their condition of vulnerabilities.

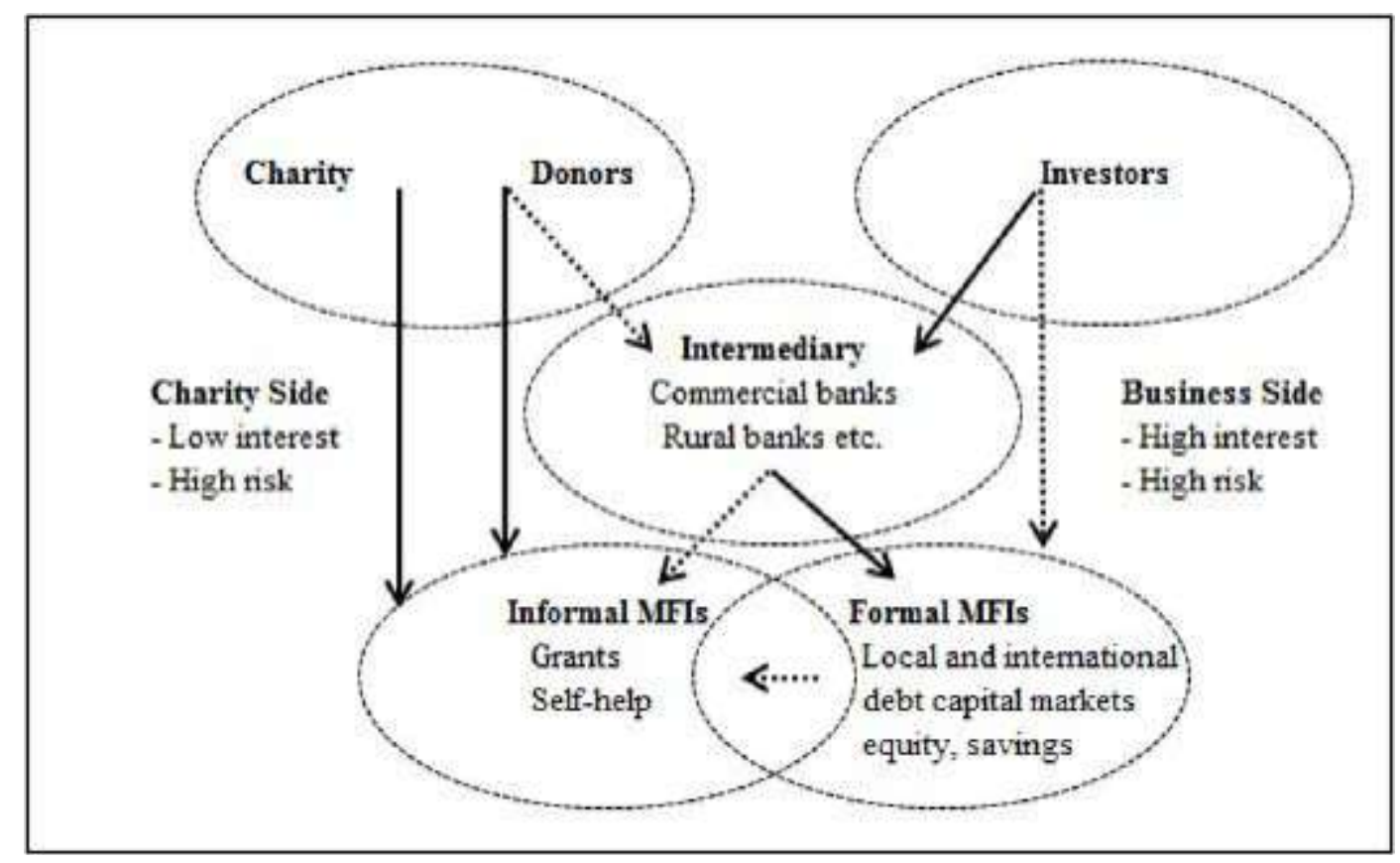

Figure1. The flow of microfinance financial resources

Table 1. Lists of Top 7 MFIs

\begin{tabular}{|c|c|}
\hline S.NO. & Name of MFI \\
\hline 1. & Arohan Financial Services Pvt Ltd. \\
\hline 2. & Disha Microfin Pvt Ltd. \\
\hline 3. & Ujjivan Financial Services Ltd. \\
\hline 4. & SKDRDP \\
\hline 5. & Equity as Micro Finance Ltd. \\
\hline 6. & Madura Micro Finance Ltd. \\
\hline 7. & Grameen Koota Financial Services Pvt. Ltd \\
\hline
\end{tabular}




\section{Microfinance in India}

Prof. Mohammad Yunus is a name for microfinance and is known as the father of micro-credit for his research work in the year 1979 when Bangladesh was in a serious condition of famine. On his visit to the Jobra village of Bangladesh Prof. Yunus encountered the problems of poor women who were forced to sell their products at very low prices due to problems of poverty. He helped some poor by providing a small loan which has been denied by the bank due to lack of collateral security against the loan. NABARD in India is a bank especially designed to work for rural and poor people and their upliftment took this idea and started the concept of Micro Finance in India.

\section{Women Condition in India}

Women in India contribute $29 \%$ of the labor force, less than the world average which is around $35 \%$ in 2004. Most of the women's work goes unpaid as the major contribution is towards unorganized and unprotected sector (Fletcher et al., 2017). Women are less represented in higher educational institutions and organized sectors which also includes the business leader. Women contribute around $40 \%$ of the labor force in the Agriculture sector having a meager 9\% landholding in India (Nayak \& Mahanta, 2009). The formal financial system is also not very welcoming for women. In comparison to $37 \%$ of the global average contribution towards GDP, women in India contribute a meager 17\%. In addition to these women face great physical insecurity (Balagobei \& Aravinthakumar, 2019; Sundari, 2020). Considering the other above factors microfinance can play important role in poverty elevation and women empowerment as the credit system so designed will act as an instrument to bring social and economic and changes in poor women's condition. The formation of a self-help group with microfinance facilities will help in poor women's empowerment and development. These women organizations act as a separate democratic group with the important instrument to change.

\section{Self Help Groups: Concepts and Measures}

SHG is based on the concept of microcredit which is instrumental for changing the condition of poor people. The concept of SHG is a group of people helping each other to achieve the economic and social goal for the betterment of society. SHG occupies a large share in the credit disbursement procedure. SHG playing a very important role in achieving the objective of economic planning which leads to the development of women and hence leads to women empowerment. SHG comprises 10 to 20 women who belong to the same class or category to resolve common problems (Agrawal, 2020). Apart from providing the opportunity of financial independence these SHG also help in the development of thrift and saving among the members. The regular saving is pooled into a fund that is disbursed among the members at an agreeable rate of interest.

\section{LITERATURE REVIEW}

The study reveals that the Self-help group helps in the economics and social development of rural women. It is a group of women who come together to achieve a common goal or objective. The Self-help group has developed confidence and provided continuous support to the poor rural women. The self-help group created many women entrepreneurs at the village level and developed leadership skills among the rural women (Dhakal \& Nepal, 2017; Kalu \& Attamah, 2021). The government of India through a microfinance scheme has supported these SHG so that it could continue the journey to elevate the poverty in rural areas. It is the SHG that has provided 
a lot of support in terms of economic and social to the poor women of rural India by providing them a better opportunity to work and earn. SHG is one of the best self-sustain and self-created models for women empowerment (Kumar, 2020). Self-help group has helped the women's to develop and create micro-enterprises in the rural areas of the country. The self Help group has given a new identity to the aural women and created the confidence and environment for the community development program.SHG has been important towards poverty elevation and women empowerment. Women empowerment helps in realizing their identities, power, and potentially in every aspect of life. The fruits of empowerment can only be achieved when women are more confident, self-motivated, and strong and have more values with greater involvement in family matters.

A study by Manimekalai and Rajcswari (2001) revealed that the SHG is the platform that created an opportunity for those having un-utilized skill knowledge.SHG act as an important tool for poverty elevation and women empowerment. This empowerment aims to realize identity and power in the very sphere of life. Women empowerment through SHG play an important role towards rural tribal poor especially women in motivating and supporting through these services within and outside such group (Murria, 2020). Vishnuvarthini and Ayyothi (2016) the women associated with SHG are getting more benefits in terms of health and socioeconomic development through the negative effect of SHG is not discussed in detail. SHG also helps in developing and maintaining socio-cultural balance in the country.

\section{Research Statement}

\section{METHODOLOGY}

The research statement studied is entitled, "Empowering women Self Help Groups through microfinance during Covid-19 A case Study of Women SHG in Meerut District" The present study focuses on the analysis of the performance of women self-help groups in Meerut with the help of mean, standard deviation, percentage, chi-square analysis, and t-test.

\section{Research Objectives}

The broad objectives of the study are as follows:

- The impact of microfinance in women empowerment, during Covid-19.

- To study the income, expenditure, and savings of the members during Covid-19.

- To analyze the performance of independent women SHGs, during Covid-19.

- To understand the role of women's Self-help groups in creating employment opportunities and poverty alleviation in Meerut.

\section{Scope of the Study}

The present study has been undertaken to evaluate the performance of female SHGs and their impact on the socio-economic conditions of members during Covid-19 in Meerut District. The study is based on empirical evidence gathered from the selected respondents to study the progress of SHGs in the Meerut District. Further, attention has also been focused on evaluating the performance of sample female SHGs and efforts have been made to examine how far SHGs help in the upliftment of socio-economic conditions of members.

\section{Nature of Data and Sources of Data}

The collection of the data is an essential part of the research. The Primary and secondary data have been collected for the research. The primary data has been collected from the Meerut 
district. The secondary data has been collected with help of various sources like newspapers, research papers, articles, and magazines and from the website.

\section{Sampling}

Meerut district comprises of twelve blocks viz. Durarara, Hastinapur, Jani, Kharkhoda, Machhara, Mawana, Meerut, Parikshitgarh, Rajpura, information from members Rohtak, Sardhana, Sarurpur. The convenience sampling method was used to select the sample for selfhelp groups and member respondents.

\section{Sampling Size}

The sample size is adopted as 300 women from female SHGs and 300 men from male SHGs in Meerut District based on the following formula.

$$
\mathbf{n}=\frac{\text { Z2.p.q.N }}{\mathrm{e} 2(\mathrm{~N}-\mathbf{1})+\mathbf{Z 2 . p . q} \text {. }}
$$

Where,

$\mathrm{n}=$ sample size

$\mathrm{N}=$ population

$\mathrm{Z}=$ value of standard variance at $95 \%$ confidence level (1.96)

$\mathrm{p}=$ probability of success $(0.5)$

$\mathrm{q}=$ probability of failure $(0.5)$

$\mathrm{e}=$ acceptable error $4 \%$ of true value

[Calculated using the formula $\mathrm{e}=\mathrm{z} .(\mathrm{p} . \mathrm{q} / \mathrm{n})$, where $\mathrm{z}=1.96$ ]

\section{Testing of Hypothesis}

The study endeavors to examine the association between demographic variables and the socioeconomic condition of members, for which the under mentioned hypotheses were framed.

- $\quad \mathbf{H}_{\mathbf{0}}$ : There is no significant relationship between the amount of saving and the amount of loan extended to the members, during Covid-19.

- $\mathbf{H}_{\mathbf{0}}$ : There is no significant relationship between the loan amount and no. of installments, effected during Covid-19.

- $\mathbf{H}_{\mathbf{0}}$ : There is no significant difference between the mean scores of family monthly income, expenses, and savings during Covid-19.

- $\quad \mathbf{H}_{0}$ : There is no significant impact of the selected demographic variables on employment generation and women empowerment during Covid-19.

- $\quad \mathbf{H}_{\mathbf{0}}$ : There is no significant relationship between demographic variables and the impact of the training program of healthcare products like masks, sanitizers, gloves.

\section{DATA ANALYSIS}

\section{General and Household Information of the Respondents}

The general and household information of the respondents is carried by using the following parameters: age, gender, category, house ownership, house type, electricity, Telephone/Mobile, sanitation facility, source of drinking water, respondent's education level, and bank account information and frequency of bank transactions. These parameters are the primary data collected for the analysis. 
Table 2. Age of Respondent

\begin{tabular}{|l|l|l|l|}
\hline S.NO & $\begin{array}{l}\text { The age group of } \\
\text { respondent }\end{array}$ & No. of Respondents & Percentage \\
\hline 1. & $20-30$ age & 81 & 27 \\
\hline 2. & $31-40$ age & 140 & 46.6 \\
\hline 3. & $41-50$ age & 53 & 17.66 \\
\hline 4. & Above 50 age & 26 & 86.66 \\
\hline & Total & 300 & 100 \\
\hline
\end{tabular}

Source: Compiled By Author From Primary Data Survey

\section{Education Level of the Respondent}

The actual education level of the respondent is presented in Table 3 In the tabulation of the primary data we divide education level into four groups- Graduation, up to matriculation, up to primary, and illiterate.

Table 3. Education Level

\begin{tabular}{|l|l|l|l|}
\hline S.NO & $\begin{array}{l}\text { The education level } \\
\text { of the respondent }\end{array}$ & No. of Respondents & Percentage \\
\hline 1. & Graduation & 19 & 6.33 \\
\hline 2. & $10^{\text {th }}$ & 42 & 14 \\
\hline 3. & Primary & 128 & 42.66 \\
\hline 4. & Illiterate & 111 & 37 \\
\hline & Total & 300 & 100 \\
\hline
\end{tabular}

Table 4. Marital Status

\begin{tabular}{|l|l|l|l|}
\hline S.NO & $\begin{array}{l}\text { Marital status of } \\
\text { the respondent }\end{array}$ & No. of Respondents & Percentage \\
\hline 1. & Married & 279 & 93 \\
\hline 2. & Unmarried & 21 & 7 \\
\hline 3. & Total & 300 & 100 \\
\hline
\end{tabular}




\section{Availability of Telephone/Mobile}

Telephonic Communication has proved a very important and significant role in communication during the lockdown and pandemic period. Since cell phones and related wireless technologies can be used to solve one of the problems, called, literacy, and it would solve the problem of communication and will help in economic development. Mobile communication has bridged the gap of digitalization and has changed the social and economic life in the rural and semi-urban areas during the pandemic.

Table 5. Availability of Telephone/Mobile

\begin{tabular}{|l|l|l|l|}
\hline S.NO & $\begin{array}{l}\text { Variable(Telephone } \\
\text { connection) }\end{array}$ & No. of Respondents & Percentage \\
\hline 1. & Yes & 177 & 59 \\
\hline 2. & No & 123 & 41 \\
\hline & Total & 300 & 100 \\
\hline
\end{tabular}

\section{RESULTS}

$\mathrm{H}_{\mathrm{o}}$ : There is no significant relationship between Savings and loan amount, during Covid-19

The monthly savings cross-tabulation can be seen in and table 5. To find out the relationship between the Amount of Saving and the Amount of loan extended to the members a Chi-square test at 0.05 level of significance was used.

Table 6. Amount Borrowed * Monthly Saving Cross Tabulation

\begin{tabular}{|l|l|l|l|l|}
\hline Factor & $\begin{array}{l}\text { Calculated chi- } \\
\text { square value }\end{array}$ & $\begin{array}{l}\text { Degree of } \\
\text { freedom }\end{array}$ & p-value & $\begin{array}{l}\text { Significance } \\
\text { level }\end{array}$ \\
\hline Savings & 11.910 & 4 & $<0.05$ & $\begin{array}{l}\text { Highly } \\
\text { significant }\end{array}$ \\
\hline
\end{tabular}

It is noted from the above table that the 'p' value is less than 0.05 and hence the result is highly significant.

$\mathrm{H}_{\mathrm{o}}$ : There is no significant relationship between the loan amount and no. of installment, during Covid-19

The cross-tabulation between the loan amount and no. of an installment is seen in table 6 . To find, A Chi-square test is used to observe the relationship between the loan amount and no. of installment. 
Table 7. Loan Amount and No. of Installment Cross Tabulation

\begin{tabular}{|l|l|l|l|l|}
\hline Factor & $\begin{array}{l}\text { Calculated chi- } \\
\text { square value }\end{array}$ & $\begin{array}{l}\text { Degree of } \\
\text { freedom }\end{array}$ & p-value & $\begin{array}{l}\text { Significance } \\
\text { level }\end{array}$ \\
\hline Loan amount & 52.695 & 6 & $<0.05$ & $\begin{array}{l}\text { Highly } \\
\text { significant }\end{array}$ \\
\hline
\end{tabular}

It is noted from the above table that the 'p' value is less than 0.05 and hence the result is highly significant. From the analysis, it is concluded that the null hypothesis is rejected and there is a highly significant association found between the loan amount and no. of installment.

\section{Number of Training Programmes Attended}

Training is the procedure of learning and improving the skill, knowledge, and attitude required for job performance. Training helps in optimum utilization and development of human resources. It boosts the morale of the person by motivation. The group members were given the training to make masks, sanitizers, and gloves for battling against covid-19.

Table 8. Number of Training Programmes Attended

\begin{tabular}{|l|l|l|l|}
\hline S.NO & $\begin{array}{l}\text { No. of Training } \\
\text { programs attended }\end{array}$ & No. of Respondents & Percentage \\
\hline 1. & 1 & 80 & 26.66 \\
\hline 2. & $2-3$ & 154 & 51.33 \\
\hline 3. & $4-6$ & 34 & 11.33 \\
\hline 4. & Above 6 & 32 & 10.66 \\
\hline & Total & 300 & 100 \\
\hline
\end{tabular}

Table 9. Impacts of Training Programmes

\begin{tabular}{|l|l|l|l|}
\hline S.NO & Impact of Training programs & No. of Respondents & Percentage \\
\hline 1. & $\begin{array}{l}\text { Making sanitizers from spirit and } \\
\text { alcohol }\end{array}$ & 95 & 31.66 \\
\hline 2. & Making DIY face masks & 125 & 41.66 \\
\hline 3. & Making gloves & 38 & 12.66 \\
\hline 4. & Other sessions & 42 & 14 \\
\hline & Total & 300 & 100 \\
\hline
\end{tabular}


$\mathrm{H}_{\mathrm{o}}$ : There is no significant relationship between education level and the impact of the training program on the working efficiency of SHG.

Table 10. Association between Impact of Training Programme Attended * Level of Education

\begin{tabular}{|l|l|l|l|l|}
\hline Factor & $\begin{array}{l}\text { Calculated chi- } \\
\text { square value }\end{array}$ & $\begin{array}{l}\text { Degree of } \\
\text { freedom }\end{array}$ & p-value & $\begin{array}{l}\text { Significance } \\
\text { level }\end{array}$ \\
\hline Education Level & 6.679 & 9 & $>0.05$ & Not significant \\
\hline
\end{tabular}

From the above table, we can see that the 'p' value is more than 0.05 and the result is not significant. From the analysis, it is concluded that an alternate hypothesis is accepted and there is no significant association found between the impact of training program attended and education level.

\section{Employment Generation}

Microfinance and employment are highly correlated as per the study. Microfinance provides an opportunity for those poor and vulnerable who are deprived of the traditional banking system. Study shows that the microcredit and SHG play a very important role in reducing the unemployment rate. During the Covid-19 pandemic, the self-help group members work very hard to come up with financial obstacles because of financial breakdown in the system, but through consistent efforts and moratorium period granted by the banks, they were able to sustain their livelihood during a pandemic.

$\mathrm{H}_{\mathrm{o}}$ : Membership experience does not influence employment generation.

Employment generation exists as a dependent variable on the independent variable on membership experience. As per the result, $\mathrm{p} \leq 0.001$ and $\mathrm{f} \geq 1$ (i.e. 12.645) hence from a null hypothesis is rejected which shows a significant impact of membership experience on employment generation. The duration of membership has a positive correlation with employment generation. The membership of SHG has an impact on employment generation and people after joining SHG during Covid-19 believe that they are more oriented towards work to fight their financial shortcomings and started their small ventures by making candles, pickles, masks, sanitizers, etc.

Table 11. Employment Generation* Membership Experience

\begin{tabular}{|l|r|r|r|r|r|}
\hline & \multicolumn{1}{|c|}{ N } & \multicolumn{1}{c|}{ Mean } & Std. Deviation & F & P \\
\cline { 1 - 5 } $\begin{array}{l}\text { Membership } \\
\text { Experience }\end{array}$ & 146 & 3.70 & 1.217 & & \\
\cline { 1 - 5 } up to 1 year & 106 & 3.53 & 1.347 & 12.645 & $<.001$ \\
\hline 1-2 years & 48 & 4.54 & .504 & & \\
\hline 2-3 years & 300 & 3.77 & 1.230 & & \\
\hline Total & & & & & \\
\hline
\end{tabular}


$\mathrm{H}_{\mathrm{o}}$ : Age group does not influence employment generation.

Age group is the independent factor and employment generation is considered as the dependent factor. To compare the mean scores of various age groups, ANOVA test procedures are applied. It is noted from the result that the 'p' value is more than 0.05 and the $\mathrm{F}$ value is more than one (2.495). Hence the result is not significant. From the analysis, it is concluded that an alternate hypothesis is accepted and there is no significant impact of age group on employment generation. There is no significant difference among the mean scores of the age group of SHG members. It is concluded that age group does not have a significant impact on employment generation. Age is not the factor that influences the employment opportunity for women to be a part of SHG.

$\mathrm{H}_{\mathrm{o}}$ : Marital status does not influence employment generation.

It is noted from the result that the ' $\mathrm{p}$ ' value is less than 0.05 and the $\mathrm{F}$ value is more than one (3.247). Hence the result is highly significant. From the analysis, it is concluded that the null hypothesis is rejected and there is a highly significant impact of marital status on employment generation. There is a significant difference among mean scores of the marital status of SHG members. It is the old belief, a man's birth completes when he takes a wife with him'. The study proves that the majorities of the members of SHG are married and are members of SHG and their family supports them to work and become more independent. During a pandemic, both men and women are working hard to earn bread butter for their life.

\section{Women Empowerment}

$\mathrm{H}_{\mathrm{o}}$ : Education level does not influence women empowerment

It is noted from the above table that the 'p' value is less than 0.05 and the $F$ value is more than one (3.437). Hence the result is highly significant. From the analysis, it is concluded that the null hypothesis is rejected and there is a highly significant impact of the level of education on women empowerment. There is a significant difference among mean scores of the level of education of SHG members. It is concluded that the level of education has a significant impact on women's empowerment. The Educated women can help and guide others in the group and can create the group working more efficiently.

Table 12. Education Level Does Not Influence Women Empowerment

\begin{tabular}{|l|r|r|r|r|r|}
\hline & \multicolumn{1}{|c|}{$\mathbf{N}$} & \multicolumn{1}{c|}{ Mean } & $\begin{array}{c}\text { Std. } \\
\text { Deviation }\end{array}$ & F & p \\
\cline { 1 - 5 } education & 19 & 3.32 & 1.293 & 3.437 & .017 \\
\hline graduation & 42 & 2.93 & 1.386 & & \\
\hline high school & 128 & 3.51 & 1.409 & & \\
\hline primary & 111 & 3.72 & 1.370 & & \\
\hline illiterate & 300 & 3.49 & 1.401 & & \\
\hline Total & &
\end{tabular}


$\mathrm{H}_{0}$ : Marital status does not influence women empowerment

Table 13. Marital Status Does Not Influence Women Empowerment

\begin{tabular}{|l|r|r|r|r|r|}
\hline & \multicolumn{1}{|c|}{ N } & \multicolumn{1}{c|}{ Mean } & $\begin{array}{c}\text { Std. } \\
\text { Deviation }\end{array}$ & F & p \\
\cline { 1 - 5 } $\begin{array}{l}\text { Marital } \\
\text { status }\end{array}$ & 279 & 3.49 & 1.404 & 3.070 & $<0.001$ \\
\hline married & 21 & 3.57 & 1.399 & & \\
\hline unmarried & 300 & 3.49 & 1.401 & & \\
\hline Total & & & & & \\
\hline
\end{tabular}

The above table shows $\mathrm{p} \leq 0.001$ and $\mathrm{f} \geq 1$ (3.070). We can see that the result is highly significant and the null hypothesis is rejected which shows marital status has a high impact on women empowerment.

\section{Family Monthly Income, Expenses, and Savings}

Income is one of the main indicators to measure the standard of living of members. The data regarding income, expenses, and saving of beneficiaries was determined at two points of time i.e. pre and post SHG membership during Covid -19 . The Family monthly income, expenses, and savings of the sample women SHGs' Members are analyzed before and after joining SHG in this section.

Null Hypothesis: $\mathbf{H}_{\mathbf{0}}$ : There is no significant difference between the Mean Family monthly income, expenses, and savings before and after joining SHG, during Covid-19.

Table 14. Paired Samples Statistics

\begin{tabular}{|l|l|r|r|r|r|}
\hline & \multicolumn{1}{|c|}{ Mean } & \multicolumn{1}{c|}{ N } & \multicolumn{1}{c|}{$\begin{array}{c}\text { Std. } \\
\text { Deviation }\end{array}$} & $\begin{array}{c}\text { Std. Error } \\
\text { Mean }\end{array}$ \\
\hline Pair 1 & $\begin{array}{l}\text { Income before joining } \\
\text { SHG }\end{array}$ & 2037.00 & 300 & 413.725 & 23.886 \\
\cline { 2 - 6 } & income after join SHG & 2300.10 & 300 & 404.469 & 23.352 \\
\hline Pair 2 & $\begin{array}{l}\text { Expenses before } \\
\text { joining SHG }\end{array}$ & 1722.33 & 300 & 391.402 & 22.598 \\
\hline \multirow{2}{*}{ Pair 3 } & $\begin{array}{l}\text { Expenses after joining } \\
\text { SHG }\end{array}$ & 1907.60 & 300 & 385.196 & 22.239 \\
& $\begin{array}{l}\text { Savings before joining } \\
\text { SHG }\end{array}$ & 99.50 & 300 & 34.739 & 2.006 \\
\cline { 2 - 6 } & $\begin{array}{l}\text { Savings after joining } \\
\text { SHG }\end{array}$ & 158.93 & 300 & 38.372 & 2.215 \\
\hline
\end{tabular}


Table 15. Paired Samples Test

\begin{tabular}{|c|c|c|c|c|c|c|c|c|c|}
\hline & & \multicolumn{5}{|c|}{ Paired Differences } & \multirow[t]{3}{*}{$\mathbf{t}$} & \multirow[t]{3}{*}{ df } & \multirow{3}{*}{$\begin{array}{c}\text { Sig. (2- } \\
\text { tailed) }\end{array}$} \\
\hline & & \multirow[t]{2}{*}{ Mean } & \multirow[t]{2}{*}{$\begin{array}{l}\text { Std. } \\
\text { Deviat } \\
\text { ion }\end{array}$} & \multirow[t]{2}{*}{$\begin{array}{l}\text { Std. } \\
\text { Error } \\
\text { Mean }\end{array}$} & \multicolumn{2}{|c|}{$\begin{array}{l}\text { 95\% Confidence } \\
\text { Interval of the } \\
\text { Difference }\end{array}$} & & & \\
\hline & & & & & Lower & Upper & & & \\
\hline Pair 1 & $\begin{array}{l}\text { income before } \\
\text { joining SHG - } \\
\text { income after join } \\
\text { SHG }\end{array}$ & -263.100 & $\begin{array}{r}100.57 \\
4\end{array}$ & 5.807 & -274.527 & $\begin{array}{r}- \\
251.67 \\
3\end{array}$ & $\begin{array}{r}- \\
45 . \\
310\end{array}$ & 299 & .000 \\
\hline Pair 2 & $\begin{array}{l}\text { expenses before } \\
\text { joining SHG - } \\
\text { expenses after } \\
\text { joining SHG }\end{array}$ & -185.267 & 53.871 & 3.110 & -191.387 & $\begin{array}{r}- \\
179.14 \\
6\end{array}$ & $\begin{array}{r}- \\
59 . \\
566\end{array}$ & 299 & .000 \\
\hline Pair 3 & $\begin{array}{l}\text { savings before } \\
\text { joining SHG - } \\
\text { savings after joining } \\
\text { SHG }\end{array}$ & -59.433 & 18.197 & 1.051 & -61.501 & $\begin{array}{r}- \\
57.366\end{array}$ & $\begin{array}{r}- \\
56 . \\
572\end{array}$ & 299 & .000 \\
\hline
\end{tabular}

The Table also shows that the $\mathrm{t}^{\prime}$ statistics, calculated as the ratio of the difference between sample means divided by the standard error of the difference. Since the P-value is less than 0.01, the hypothesis was rejected. Hence there is a highly significant difference in the Mean family income, expenses, and savings after joining the SHG during covid-19. This indicates that there is a significant increase in the Mean Scores of family income, expenses, and savings after joining SHG showing the Economic Empowerment of women SHGs members.

\section{FINDINGS AND SUGGESTIONS}

\section{- Promotion of High Saving Habit In Female SHG}

It is noticed that more than one-half of the sample respondents of female SHGs have become members for promoting saving habits and inculcating the habit of saving through their surplus income. It indicates that Female SHGs have pervaded the minds of women and thereby inculcated the habit of thrift and savings among rural and urban poor women during a pandemic which has helped them to fight the difficult times in the Meerut district.

\section{- Increase In the Family Income of Group Members}

The study also reveals that there is a significant increase in the mean scores of income, savings, and expenses level of members of female SHG. After joining the group the income level of members is higher and it is shown their sources of income have increased after joining the group. 


\section{- Marital Support}

The majority of the respondents are married and marriage is support in disguise. Marital status has a significant impact on the life of female members of self-help groups. Married people feel more confident than unmarried ones. Marital status has a highly significant impact on the social aspects of female SHG.

\section{- Fighting Spirit During Pandemic}

Though the stitching and tailoring are not the primary or part of economic activity as for as the SHG is concerned but during the cover pandemic crisis these SHG workers decided to produce the mask so that the shortage of mask in the market can be mitigated.

\section{- Communication Empowerment}

One of the major contributions by the SHG in the district was to make the women be connected by providing them training and information regarding the use of internet technology with help of smart phones. They have been trained on how to make use of social media.

\section{- Female SHG Helps to Reduce Poverty and Helps In Women Empowerment}

After joining the group female members feel more financially empowered and support their family members socially and economically. They feel the sense of pride of being recognized by the public in general as an independent working member supporting her family. Poverty alleviation is higher in Female SHG.

\section{- The opinion of Different Training Camps}

The study found that all the respondents of female SHG underwent a training program to fight against the pandemic. They learned to make health care products some have started a new business from attending the training program and some went on with their traditional business. The new businesses that are undertaken by them include Mask making, herbal disinfectant, and hand washers, coir products, agarbatti, pickles, fancy stores, etc.

\section{CONCLUSION}

In the COVID-19 pandemic, it is implausible to mark the tedious and courageous efforts put in by all the volunteers to meet the essential requirements. The voluntary organizations/individual volunteers or other support agencies are consistently working to reach out to such people with food and other essential commodities. Women's Self-help groups are working extremely great in India and are fighting to meet the daily challenges with full courage, safety, and enthusiasm. Despite the own sufferings, our women are collectively working around the area and taking care of the work with social distancing, making masks, sanitizers, gloves, cooking, and serving hot food to children in the initial days of the lockdown and also the whole pandemic period to sustain their nutrition. Women Self Help Groups are an invaluable resource in these difficult times. Over the past two decagons of the Bank's association, India's SHG movement has developed from microsavings and credit groups that hunted to empower poor rural females, into one of the world's largest platforms of the poor. Today, 67 million Indian women are active members of 6 million SHGs. The Groups beyond the country are functioning intensely to make up the shortfall of masks and personal protective equipment (PPE). The attempt of these women functioning in SHGs has been remarkable 
in the fight against the pandemic, where they are not only defending themselves but are serving the economy also and making their efforts at a large scale to revive the economy from this depression.

\section{REFERENCES}

Agrawal, D. (2020). An Empirical Study on Women Empowerment Through Self Help Groups (Special Reference to Ujjain District of MP). Accent Journal of Economics Ecology \& Engineering, 5. Retrieved from https://ssrn.com/abstract=3578466.

Balagobei, S., \& Aravinthakumar, S. (2019). Impact of Microcredit on Living Standard of Dairy Entrepreneurs: Special Focus on Oddusuddan DS Division in Mullaitivu District. Indian Journal of Finance and Banking, 3(2), 43-48. https://doi.org/10.46281/ijfb.v3i2.456

Davies, S. E., \& Bennett, B. (2016). A gendered human rights analysis of Ebola and Zika: locating gender in global health emergencies. International Affairs, 92(5), 1041-1060. https://doi.org/10.1111/1468-2346.12704.

Dhakal, C., \& Nepal, G. (2017). Microfinance Services and Poverty Level of Rural Farmers of Syangja District of Nepal. International Journal of Accounting \& Finance Review, 1(1), 31-41. https://doi.org/10.46281/ijafr.v1i1.16

Fletcher, E., Pande, R., \& Moore, C. M. T. (2017). Women and work in India: Descriptive evidence and a review of potential policies. https://dx.doi.org/10.2139/ssrn.3116310.

Kalu, C. U., \& Attamah, N. (2021). Globalization, Democracy, and Inequality. Decent Work and Economic Growth, 498-507. https://doi.org/10.1007/978-3-319-95867-5_116.

Kumar, D. (2020). Mitigating Socio-Economic Impact of Covid-19: A Collaborative Approach of Self Help Groups (SHGs) and Micro Small and Medium Enterprises (MSME). , 174. Retrieved from https://www.bhumipublishing.com/wpcontent/uploads/2020/08/COVID-\%E2\%80\%93-19-Impact-and-

Response.pdf\#page $=184$.

Kusugal, P. S. (2020). Women Empowerment through Self-Help Groups: An Empirical Study in Haveri District of Karnataka. Women Empowerment, 84. Retrieved from http://drnishikantjha.com/papersCollection/Women\%20Empowerment\%20.pdf\#page=93

Kaladhar, K. (1997). Microfinance in India: Design, structure, and governance. Economic and Political Weekly, 2687-2706. Retrieved from https://www.jstor.org/stable/4405979.

Llewelyn, S. (2007). A neutral feminist observer? Observation-based research and the politics of feminist knowledge-making. Gender \& Development, 15(2), 299-310. https://www.tandfonline.com/doi/abs/10.1080/13552070701391755.

Mahajan, S. S., \& Kamble, C. B. (2011). Government Support to Women Entrepreneurship: A Study of Programmes Implemented By MAVIM. Indian Streams Research 
Journal, 1(11),

130-134.

Retrieved

from https://www.academia.edu/download/31619629/602.pdf.

Manimekalai, N., \& Rajeswari, G. (2000). Empowerment of women through Self-Help Groups (SHGs). Margin, 32(4), 74-87. Retrieved from https://www.cabdirect.org/cabdirect/abstract/20013123986.

Murria, P. (2020). Lending Through Women Self Help Groups: A Macro Move For inclusive Growth In India. Editorial Board,9(11), 180. Retrieved from http://ijmer.s3.amazonaws.com/pdf/volume9/volume9-issue11(9)-2020.pdf\#page=188.

Mengstie, B., \& Singh, A. (2020). Ethiopian Women Economic Empowerment Through Microfinance. Indian Journal of Finance and Banking, 4(2), 51-57. https://doi.org/10.46281/ijfb.v4i2.708

Nayak, P., \& Mahanta, B. (2009). Women empowerment in India. Retrieved from https://mpra.ub.uni-muenchen.de/24740

Rathod, M. K., \& Pooja, D. (2015). Impact of MAVIM activities on the empowerment of rural women. Indian Research Journal of Extension Education, 15(1), 8-11. Retrieved from http://www.seea.org.in/vol15-1-2015/02.pdf

Rogaly, B. (1996). Micro-finance evangelism, 'destitute women', and the hard selling of a new anti-poverty formula. Development in practice,6(2), 100-112. Retrieved from https://www.tandfonline.com/doi/abs/10.1080/0961452961000157654.

Rhyne, E., \& Otero, M. (2006). Microfinance through the next decade: Visioning the who, what, where, when, and how. Boston, MA: Accion International. Retrieved from https://www.findevgateway.org/sites/default/files/publications/files/mfg-en-papermicrofinance-through-the-next-decade-visioning-the-who-what-where-when-and-how2006_0.pdf.

Sundari, S. (2020). Structural Changes and Quality of Women's Labour in India. The Indian Journal of Labour Economics, 63(3), 689-717. https://doi.org/10.1007/s41027-02000245-2

Singh, R., Roy, S., \& Pandiya, B. (2020). Antecedents of Financial Inclusion: Evidence from Tripura, India. Indian Journal of Finance and Banking, 4(2), 79-92. https://doi.org/10.46281/ijfb.v4i2.745.

Tankha, A. (2012). Banking on self-help groups: Twenty years on. Sage Publications India.

Vishnuvarthini, R., \& Ayyothi, A. M. (2016). The role of SHG in women empowerment-A critical review. IOSR Journal of Economics and Finance, 7(3), 33-39. Retrieved from https://smartlib.umri.ac.id/assets/uploads/files/ecb5a-d0703023339.pdf. 
Venugopalan, K. (2014). Influence of Kudumbasree on Women Empowerment-a Study. IOSR Journal of Business and Management, 16(10), 35-44. Retrieved from https://kudumbashree.org/storage/files/8zhyr_studyrepot11.pdf.

\section{Copyrights}

Copyright for this article is retained by the author(s), with first publication rights granted to the journal. This is an open-access article distributed under the terms and conditions of the Creative Commons Attribution license (http://creativecommons.org/licenses/by/4.0/) 